\title{
Geophysical evidence of first stages of inflation in Domuyo volcanic center in northwestern Neuquén province, Argentina
}

\author{
Laura B. Godoy a,b, ", Silvina Nacif ${ }^{\mathrm{a}, \mathrm{b}}$, Marianela Lupari ${ }^{\mathrm{a}, \mathrm{b}}$, Héctor P.A. García ${ }^{\mathrm{a}, \mathrm{b}}$, \\ Sebastián Correa-Otto ${ }^{\mathrm{a}, \mathrm{b}}$, Iván Melchor ${ }^{\mathrm{c}, \mathrm{d}}$, Stefanie N. Pechuan ${ }^{\mathrm{a}, \mathrm{b}}$, Juan P. Ariza ${ }^{\mathrm{a}, \mathrm{b}}$, \\ Mario Ernesto Gimenez ${ }^{\text {a,b }}$, Alberto T. Caselli ${ }^{\text {c,d }}$ \\ ${ }^{a}$ CONICET (Consejo Nacional de Investigaciones Científicas y Técnicas), Av. Rivadavia 1917, C1033AAJ, Argentina \\ ${ }^{\mathrm{b}}$ Instituto Geofísico Sismológico F. Volponi, FCEFyN, Universidad Nacional de San Juan (UNSJ), Ruta 12 km 17 Marquesado, Rivadavia, San Juan, Argentina \\ c Universidad Nacional de Río Negro, Instituto de Investigación en Paleobiología y Geología, Río Negro, Argentina \\ ${ }^{\mathrm{d}}$ CONICET, Instituto de Investigación en Paleobiología y Geología, Río Negro, Argentina
}

\section{A R T I C L E I N F O}

\section{Keywords:}

Volcanism

Domuyo

Geothermal field

Micro seismicity

Thermal anomaly

\begin{abstract}
A B S T R A C T
Cerro Domuyo, in northwestern Neuquén province of Argentina, shows notable geothermal activity, although it is located at a considerable distance from the actual volcanic arc. Many studies have been developed in this area with the aim of investigating its geothermal field. Despite these efforts, the characterization of the dynamic activity in the area is still poorly known. This work shows the results of a network of seismological stations, which registered volcano-tectonic, long-period and hybrid events. A large number of volcano-tectonic events concentrated mostly in the Cerro Domuyo geothermal area were detected. These events can be divided into two groups, those that occurred at shallow depths below the geothermal area and those at greater depths below the high region of Cerro Domuyo. Shallow events were located around the Manchana Covunco fault and many of them were particularly clustered at its intersection with the Humazo fault. Seismicity in the area shows that these faults are continually active due to fluid movement, as was evidenced by the hydrothermal manifestation of the Humazo in 2003. Moreover, new studies provide evidence that the Cerro Domuyo is experiencing an important inflation caused by a magmatic body. Deep volcano-tectonic events are evidencing this activity. Considering the large distance between the actual volcanic arc and the study region, and the high density of shallow volcanotectonic events, it is highly likely that this magmatic body is increasing the geothermal activity. Additionally, the aeromagnetic anomaly over Cerro Domuyo is showing a thin magnetic crust of less than $6 \mathrm{~km}$, suggesting a clear link between the geophysical results and the inflation in Cerro Domuyo.
\end{abstract}

\section{Introduction}

The subduction of the Nazca plate below the South American plate controls, among other factors, the growth rate of the Andes. The Nazca plate subduction angle determines the increase in the seismicity in the flat subduction segment or the volcanic activity in the normal subduction segment. In response to this phenomenon, high enthalpy geothermal fields heated by deep magmatic systems are developed in the western margin of South America (Cardoso et al., 2010). In these areas, the presence of impermeable horizons seals the systems preventing the escape of the hot fluids allowing the development of deep reservoirs. Thus, a geothermal field where the meteoric waters that circulate through the permeable rocks are heated by a volcanic surge constitute important reservoirs of renewable energy.

In Argentina, seven high enthalpy zones are recognized as the most important in terms of stored energy (Pesce, 2015): Copahue and Domuyo (Neuquén province), Tuzgle (Jujuy province), Los Despoblados (San Juan province), Termas de Río Hondo (Santiago del Estero province) and, Los Molles and Peteroa (Mendoza province). The study area, Domuyo geothermal field, comprises a high enthalpy system $\left(>220^{\circ} \mathrm{C}\right)$ located to the northwest of the Neuquén province on the western slope of the Domuyo volcanic complex (Fig. 1). An important geochemical survey of the main thermal waters discharging in the southwestern part of the Cerro Domuyo was presented by Chiodini et al. (2014). These authors underlined the high value of thermal energy release from this site, which is the second highest measured-advective heat flux from any

\footnotetext{
* Corresponding author. CONICET (Consejo Nacional de Investigaciones Científicas y Técnicas), Av. Rivadavia 1917, C1033AAJ, Argentina.

E-mail address: laurabeatrizgodoy@gmail.com (L.B. Godoy).
} 

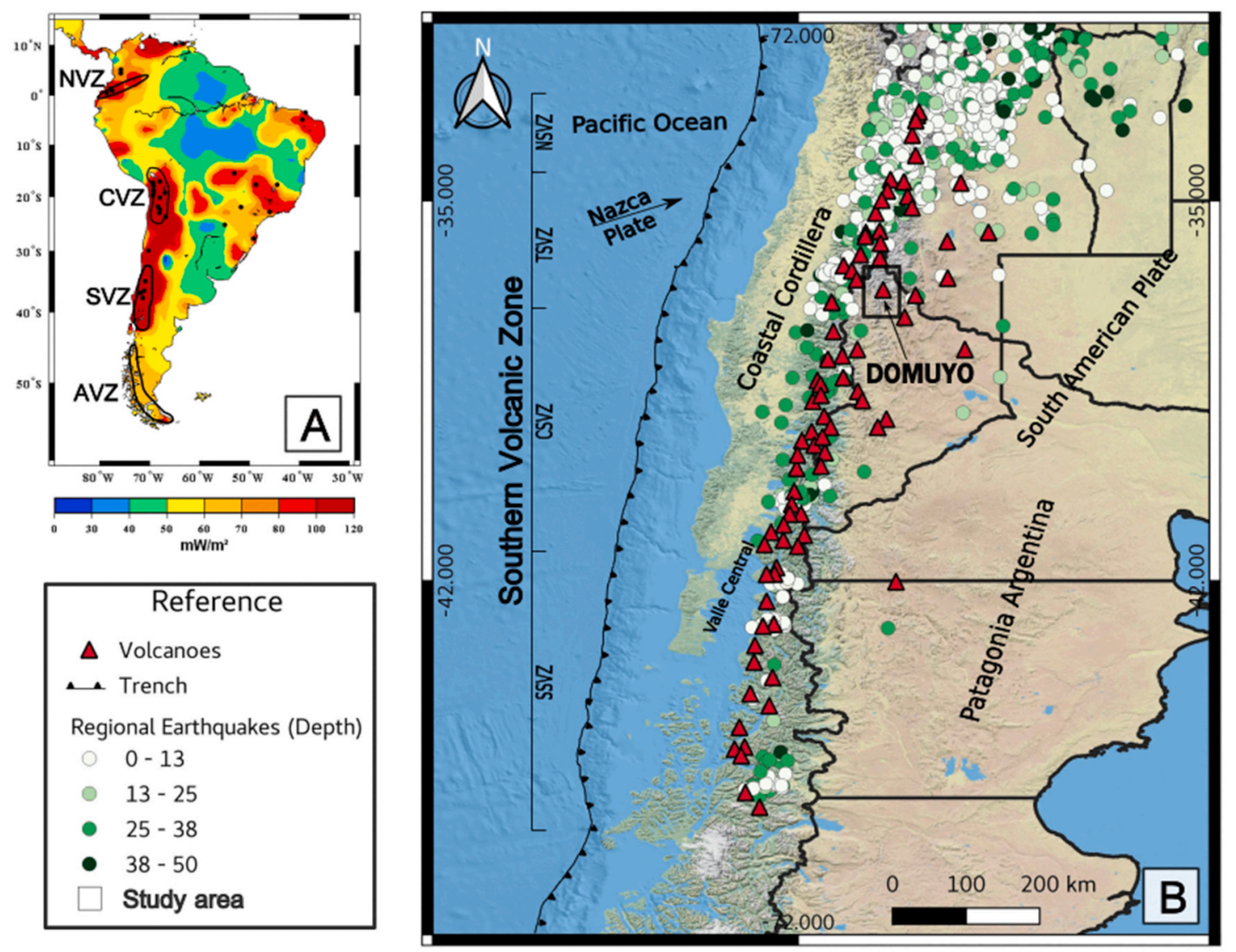

Fig. 1. A) Heat flow map of South America (Modified from Cardoso et al., 2010). In black lines, the Northern, Central, Southern and Austral Volcanic Zones are indicated. B) Arc and retroarc volcanoes and regional intraplate earthquakes (see reference for color scale) up to $50 \mathrm{~km}$ depth from 1980 to 2018 (obtained from the National Earthquake Information Centre, USGS). Seismicity increases in the Andes, decreasing towards the south (SVZ). (For interpretation of the references to colour in this figure legend, the reader is referred to the Web version of this article.)

terrestrial hydrothermal system after Yellowstone.

Although the Cerro Domuyo is considered an extinct volcanic system (Pesce, 2013), it abruptly started to inflate since 2014 to the present (Lundgren et al., 2018; Astort et al., 2019). In order to study these changes and, since seismic monitoring is probably one of the most robust tools to characterize dynamic activity in volcanos (Chouet, 1992, 2003), a local seismological network was deployed for the first time at the Cerro Domuyo geothermal region. This network registered during the first stage of inflation between December 2015 to March 2016. Additionally, aeromagnetic data for this region was interpreted and Curie depth points were obtained. In this work, we present the registered seismic signals with special focus on the volcano-tectonic seismicity and its relation with the Curie depth points for the study area.

\section{SEISMO-TECTONIC setting}

The study area is located in the Southern Volcanic Zone (SVZ) developed between $33^{\circ}$ and $46^{\circ} \mathrm{S}$ (Fig. 1). In this area the eastward normal-dip $\left(\sim 30^{\circ}\right)$ of the Wadatti-Benioff zone controls the current arc related volcanic activity (Thorpe and Francis, 1979; Thorpe, 1984) and the high background heat flow. The SVZ is divided into four segments: Northern segment (NSVZ: 33-34.5 ${ }^{\circ}$; Hildreth and Moorbath, 1988), Transition segment (TSVZ: $34.5-37^{\circ}$ S; Tormey et al., 1991; Dungan et al., 2001), Central segment (CSVZ: 37-41.5 ${ }^{\circ}$; Hickey-Vargas et al., 1984, 1986, 1989; López-Escobar et al., 1995a), and Southern segment (SSVZ: 41.5-46º S; López-Escobar et al., 1993). The Cerro Domuyo is located in the Central segment.

The Domuyo volcanic complex (Fig. 2), the highest mountain in Patagonia, is placed at the northern edge of the Cordillera del Viento. Formed by a regional dome structure, this anticline exposes in its nucleus the Neuquén basin basement rocks. Such fold forms a large dome that dips in four directions NW, NE, SE and SW (Lisjak, 2007). The Cerro Domuyo belongs to a series of young volcanoes located in the Andes Neuquinos. The set of volcanoes represented by the Cerro Domuyo, Monte la Cruzada, Tromen and Carrere are NW-SE oriented (Mas et al., 2011). The stratigraphy of the area is characterized by acontinuous series of Jurassic, Cretaceous and Tertiary sedimentary rocks (Keidel, 1925; Yrigoyen, 1972, 1979). The northern extension of these outcrops reaches the Mendoza province. At the study region and surrounding areas, the Cordillera Principal can be divided into two sectors: the northwestern sector which is represented by the Guanacos fold and thrust belt $\left(36^{\circ}-38.5^{\circ} \mathrm{S}\right)$ and the northeastern sector which is represented by the Chos Malal fold and thrust belt in the Barrancas block $\left(70^{\circ}\right.$ $70.5^{\circ} \mathrm{W}$ ) where the Cerro Domuyo volcanic complex is emplaced.

The Chos Malal fold and thrust belt involves more than $4.500 \mathrm{~m}$ of sediments that were deposited in the Neuquén basin. The sedimentary and basement rocks were deformed during the Andean orogeny with the development of a thick-skinned fold and thrust belt. The basement rocks that can be observed on the western flank of the Cordillera del Viento are mainly composed of Palaeozoic meta-sedimentary and volcano-clastic rocks that host Permian-Triassic igneous rocks of the Choiyoi Group (Stipanicic et al., 1968; Zappettini et al., 1987; Zanettini, 2001; Llambías 


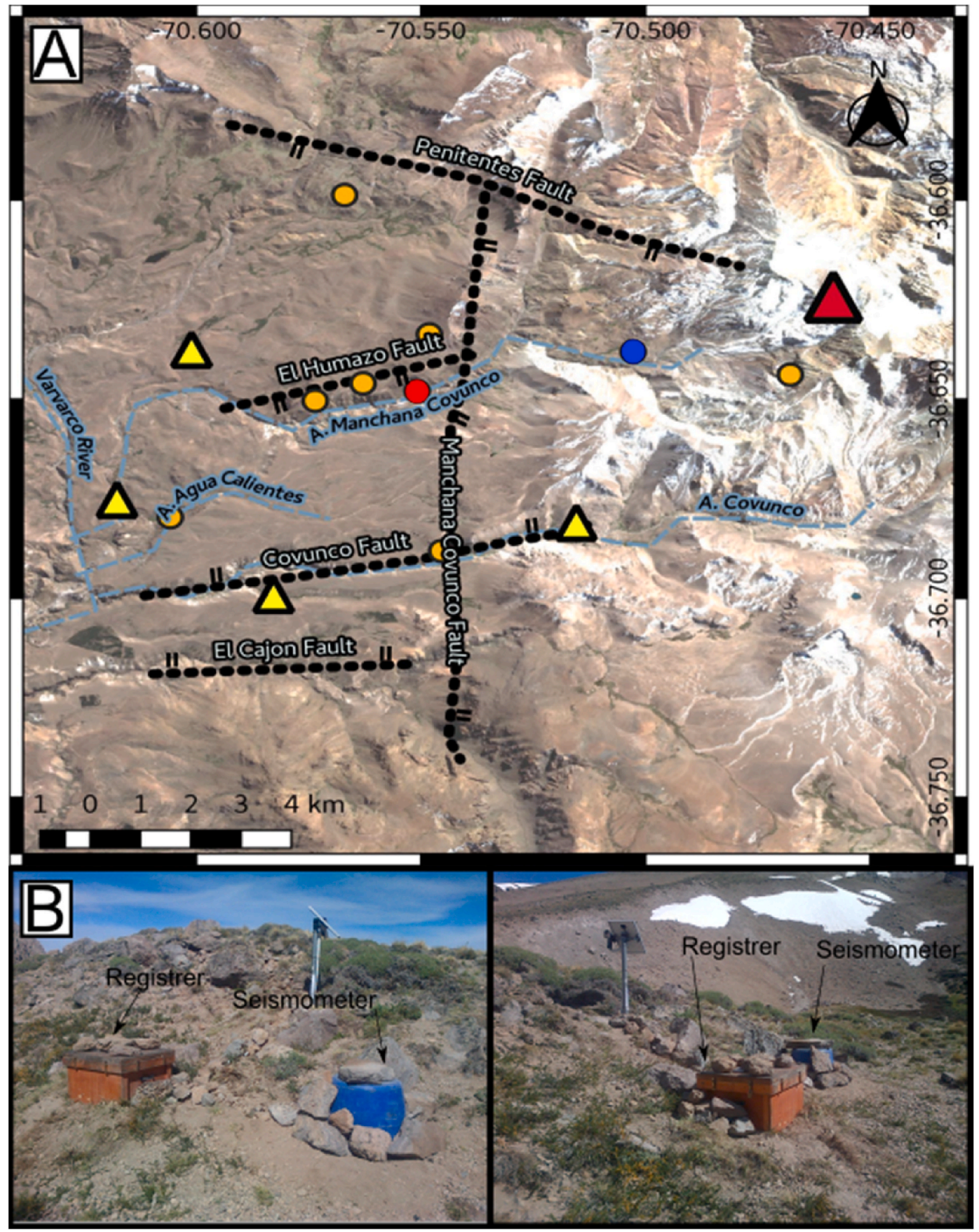

Fig. 2. A) Satellite image of the Domuyo region. The red triangle represents the peak of the Cerro Domuyo and orange circles, the water springs in the geothermal area. The red circle denotes the Humazo geothermal field and the blue circle, the Bramadora geothermal field. The dotted lines represent the lineaments for the Penitentes fault (Mariot, 2008), El Humazo, Covunco and El Cajón faults (Galetto et al., 2018) and the Manchana Covunco fault (Pesce, 1987). The locations of the seismological stations are shown with yellow triangles. B) Photographs showing the installation of two seismological stations of the Domuyo network. (For interpretation of the references to colour in this figure legend, the reader is referred to the Web version of this article.) 


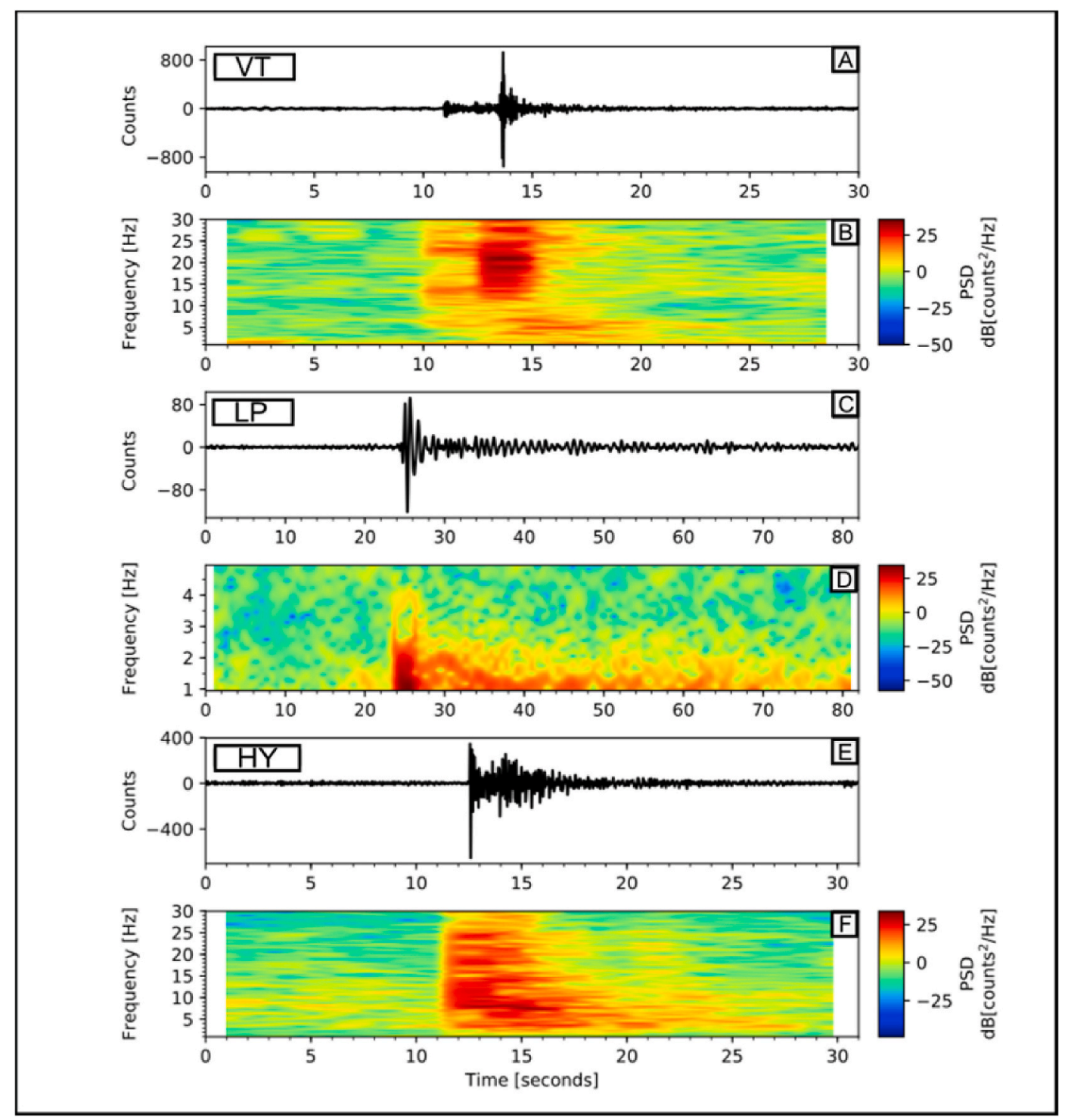

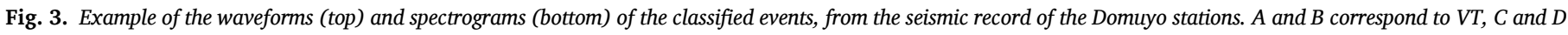

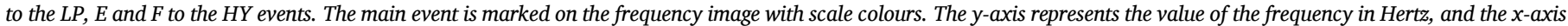
the time in seconds. (For interpretation of the references to colour in this figure legend, the reader is referred to the Web version of this article.)

\section{et al., 2007).}

The western foothill of the Cerro Domuyo presents a zone of high hydrothermal potential, which was preliminary studied through geophysical and geochemical measure ments by the Japan International Cooperation Agency (JICA, 1983, 1984). Based on the analysis of water and gas samples of the Cerro Domuyo volcanic complex, Tassi et al. (2016) suggested the existence of two aquifers. These water reservoirs aremagmatic-influenced and are located at different depths between 400 and $600 \mathrm{~m}$ and $2-3 \mathrm{~km}$ and would be connected to each other. In this region, the structures can be divided into two systems based on their orientation. The N-S system includes the Manchana Covunco fault (Pesce, 1987), which is considered a continuation of the Atreuco Butalón fault. The W-E system is composed of a set of faults, which include from north to south, the Penitente fault (Mariot, 2008), and the El Humazo, Covunco and Cajón faults (Galetto et al., 2018). The Manchana Covunco normal fault with in the N-S system orientation and dipsto the east and hosts the main geothermal springs (Rincón de las Papas, El Humazo, Las Olletas, and Los Tachos). Galetto et al. (2018), proposed that this fault is responsible for the flow of hot fluids from a deep-located heat source and is acting as a source to the western area of the geothermal field through the west-east oriented normal faults.

\section{Methodology and data analysis}

The surrounding area of a volcano is a very dynamic system in which the flow of fluids, the pressure generated by them and the tectonic movement produce associated seismicity. These events can be detected with an adequate seismological network and, depending on the origin of the signal, a waveform with a characteristic frequency spectrum can be observed. These analyses provide key information to understand the behaviour of the volcano and its surroundings.

In this sense, and for the first time in the region with hydrothermal evidence (Southwest of Cerro Domuyo), a seismological network was installed. This network consisted in 4 short period vertical component stations with S13 seismometers (Geotech) (Fig. 2). Records, from December 14th, 2015 to March 13th, 2016, consisted of 100 samples/ second continuous data in proprietary Reftek format. These data were later converted to SEISAN format (Havskov and Ottemoller, 2001) and organized in a SEISAN data base. The complete data base was visualized and classified according to its waveform and its frequency domain. The analysis was achieved with 15-min length windows and events (example: Fig. 3) were classified as volcano - tectonic (VT), long - period (LP) and hybrid (Hy) according to Lahr et al. (1994) and McNutt and Roman 


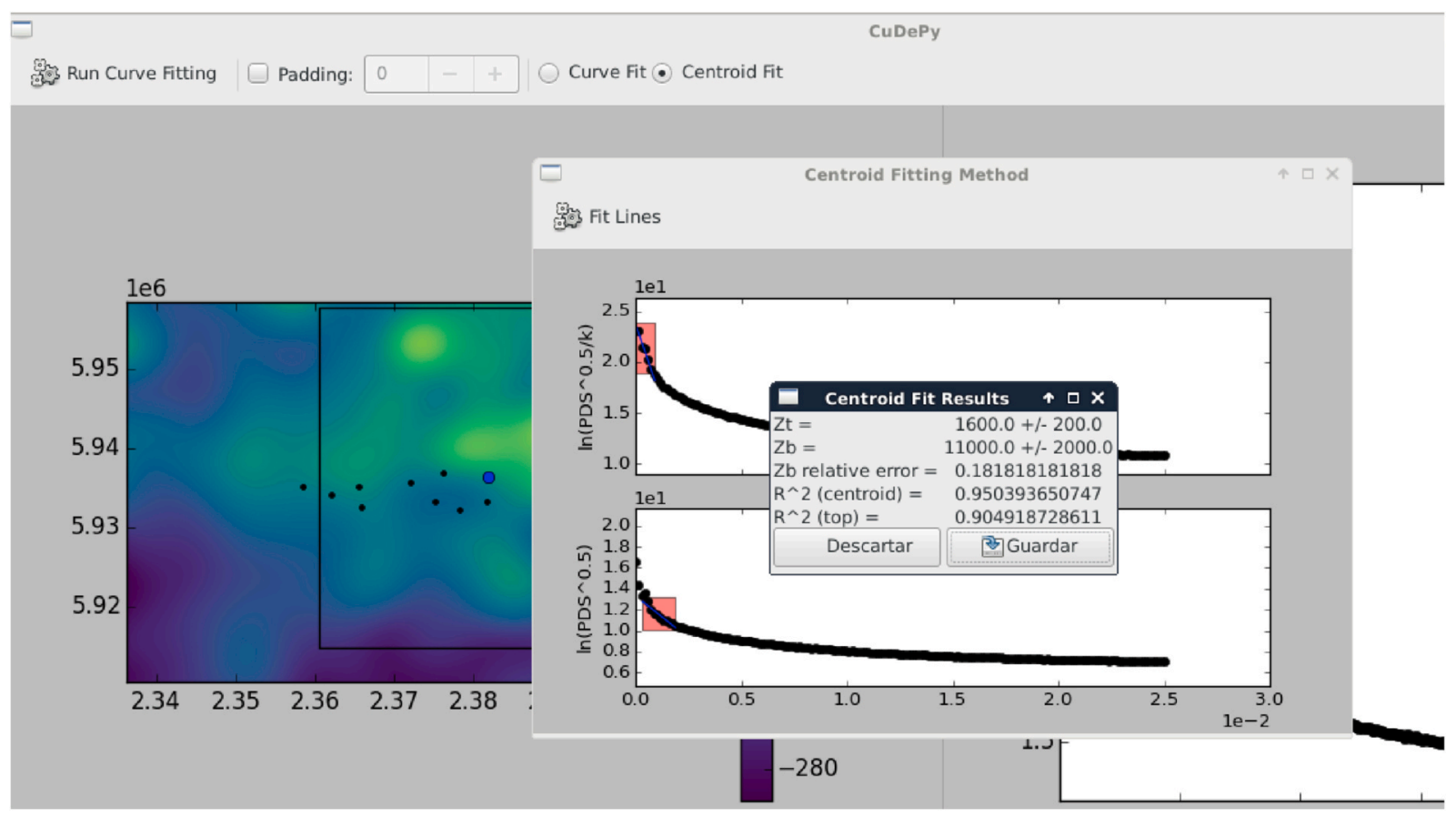

Fig. 4. Curie point depth calculation example with CuDePy software. Black dot in the left window represents the obtained depths. CuDePy operates in variable windows looking for the optimal size for each region.

\section{(2015).}

The volcano-tectonic signals can be generated by brittle rock failure induced by fluid movements in the crust beneath the volcano. In this kind of earthquakes, the beginning of the signal is usually impulsive and can be identified with the arrival of the $\mathrm{P}$ wave. VT earthquakes have clear high-frequency P arrivals with peak frequencies above $15 \mathrm{~Hz}$. The seismogram of a typical VT earthquake is dominated by the P and $\mathrm{S}$ phases, a very short coda and the difference between $\mathrm{P}$ and $\mathrm{S}$ arrivals of less than $5 \mathrm{~s}$. Conversely, LP earthquakes are usually produced by injection of fluid in the crust and/or inside the volcano and are related to pressure changes during the unsteady transport of fluid (Lahr et al., 1994). In this work, only VT events were located.

$\mathrm{P}$ and $\mathrm{S}$ wave arrival identification was achieved using SEISAN multitrace view and the location parameters were obtained using Hypocenter 3.0 (Lienert, 1994). The theoretical travel times were obtained using the 1-D velocity model from Bohm et al. (2002), calculated for the Southern Andes between $36^{\circ}$ and $40^{\circ} \mathrm{S}$ latitude. Nevertheless, the determination of the locations can be affected by the presence of significant lateral variations in the Earth that are not included in the one-dimensional velocity models. On the other hand, joint hypocenter determination (JHD) technique (Pujol, 2000) considers the neglected lateral velocity variations in the $1-\mathrm{D}$ velocity model through the joint location determinations and station corrections. For this reason, in the seismicity results, only those determined with the JHD technique are shown. In order to obtain the local magnitude, the instrumental response for the seismometer - seismograph equipment was calculated with PDCC (Portable Data Collection Center software).

Unpublished aeromagnetic data acquired during 2004-2005, were interpreted. These data were measured in W-E lines every $2 \mathrm{~km}$ with N-S control lines spaced every $10 \mathrm{~km}$. Sensors were located at an altitude of $1 \mathrm{~km}$, therefore data resolution of $1 \mathrm{nT}$ is expected. Total Magnetic Intensity values (TMI) were gridded using the minimum curvature technique (Briggs, 1974) at a cell size of $500 \mathrm{~m}$ and corrected for diurnal variation.

The dipolar nature of magnetic anomalies usually introduces some complexity in the interpretation of different geological structures.
Consequently, to improve the interpretation of this anomaly, the residual magnetic anomalies were transformed using the reduced-to-the-pole (RTP) filter in the software Oasis Montaj ${ }^{\circledR}$ with inclination and a declination values of $-38^{\circ}$ and $6^{\circ}$, respectively. This filtering technique is used to centre anomalies above their source. The RTP is usually applied to the magnetic data to minimize the asymmetry caused by the non-vertical direction of magnetization assuming that the remaining magnetism is negligible compared to the induced one (Baranov, 1957; Phillips, 2007).

The magnetic crust can be represented by a horizontal plate of infinite lateral extension, whose roof, base and centre are at depths $\mathrm{Zt}$, $\mathrm{Zb}$ and $\mathrm{Zc}$, respectively. The roof $(\mathrm{Zt})$ and the centroid $(\mathrm{Zc})$ of the magnetic basement were calculated from the radial power spectrum of the magnetic anomalies (Blakely, 1995) applying the method of Tanaka et al. (1999). In these calculations, the base of the plate (Zb) (depth to the Curie point) is determined by equation (1)

$Z b=2 Z c-Z t$

The depths Zt and Zc are estimated by a linear regression of the high

Table 1

Curie point depth determination data. The plane coordinates of each point, the width of the window, $\mathrm{Zt}, \mathrm{Zb}$ and the error generated in $\mathrm{Zb}$ are represented.

\begin{tabular}{lllllll}
\hline $\mathrm{x}$ & $\mathrm{y}$ & $\begin{array}{l}\text { Window } \\
\text { Width (m) }\end{array}$ & $\mathrm{Zt}(\mathrm{m})$ & $\begin{array}{l}\mathrm{Zt}_{\text {err }} \\
(\mathrm{m})\end{array}$ & $\mathrm{Zb}(\mathrm{m})$ & $\begin{array}{l}\mathrm{Zb}_{\text {err }} \\
(\mathrm{m})\end{array}$ \\
\hline $2,358,478$ & $5,935,132$ & 42,818 & 1800 & 200 & 13,000 & 2000 \\
$2,362,109$ & $5,934,130$ & 42,818 & 1900 & 200 & 10,000 & 1000 \\
$2,365,489$ & $5,935,132$ & 42,818 & 1400 & 100 & 9000 & 1000 \\
$2,365,865$ & $5,932,628$ & 42,818 & 2100 & 200 & 12,000 & 2000 \\
$2,372,125$ & $5,935,633$ & 42,818 & 1900 & 200 & 11,000 & 2000 \\
$2,376,256$ & $5,936,885$ & 42,818 & 1600 & 200 & 10,000 & 2000 \\
$2,375,130$ & $5,933,254$ & 42,818 & 1900 & 200 & 9000 & 1000 \\
$2,378,259$ & $5,932,253$ & 42,818 & 1300 & 100 & 11,000 & 1000 \\
$2,381,765$ & $5,933,379$ & 42,818 & 1600 & 200 & 11,000 & 2000 \\
$2,381,890$ & $5,936,384$ & 42,818 & 1600 & 200 & 11,000 & 2000 \\
$2,385,897$ & $5,934,005$ & 42,818 & 1260 & 90 & 12,000 & 1000 \\
$2,387,399$ & $5,935,382$ & 42,818 & 1500 & 200 & 11,000 & 1000 \\
$2,384,519$ & $5,936,631$ & 42,818 & 1500 & 200 & 11,000 & 2000 \\
\hline
\end{tabular}


and frequency values of the average radial spectrum (Tanaka et al., 1999; Espinosa-Cardeña and Campos-Enriquez et al., 2008; Hsieh et al., 2014).

It should be clarified that the Curie temperature depends on the mineralogy of the magnetic bodies. The intensity of the magnetization is controlled by the magnetization of the present magnetic phases and by its volume fraction in the crust. Different minerals have different Curie temperatures and this requires different locations of the Curie isotherm that limits the thickness of the magnetic crust. Thus, a Curie surface may not be an isothermal surface.

The calculation of the Curie depth points was carried out considering the aeromagnetic data through the CuDePy program (Soler, 2015). This software, carried out at the Instituto Geofísico Sismológico Volponi (IGSV), works in a Python platform. For this contribution, the long wave lengths of the total magnetic field in different variable windows were analysed, covering the aeromagnetic data area (Fig. 4). As a result, $\mathrm{Zt}$ and $\mathrm{Zb}$ depths were assigned to the coordinates of each window centre (Table 1).

\section{Results and discussion}

A great variety of seismic events were detected by the Domuyo local network. Among these signals 60 hybrids, 106 long periods and 538 volcano-tectonic were identified. From the $538 \mathrm{~V}$ T events and considering error in their location parameters, two selections of events were done: a "loose"one and a "tight" one. In the "loose" one we selected those events with error in their location parameters determination of less than $8 \mathrm{~km}$, obtaining a total of 255 VT events. In the "tight" one we

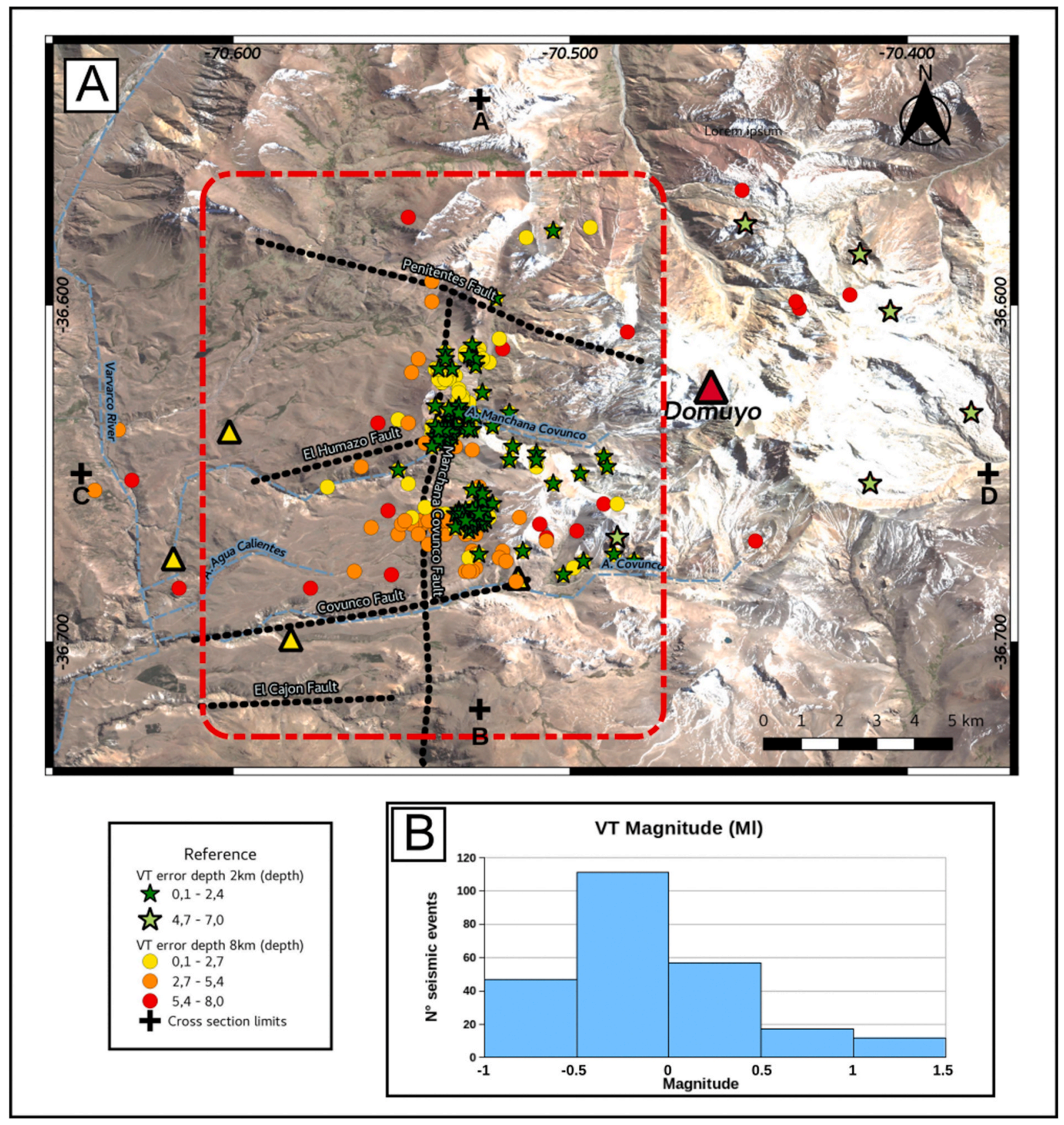

Fig. 5. A) Location of the VT events found by the Domuyo network. Map: VT events epicenters (circles and stars) plotted by depth showing their distribution according to the Manchana and Humazo faults. The geothermal region is delimited with a red box. The sections marked on the map with a cross are found in Fig. 6 . The locations of the seismological stations are shown in yellow triangles. B) Histogram of the VT events magnitudes. (For interpretation of the references to colour in this figure legend, the reader is referred to the Web version of this article.) 


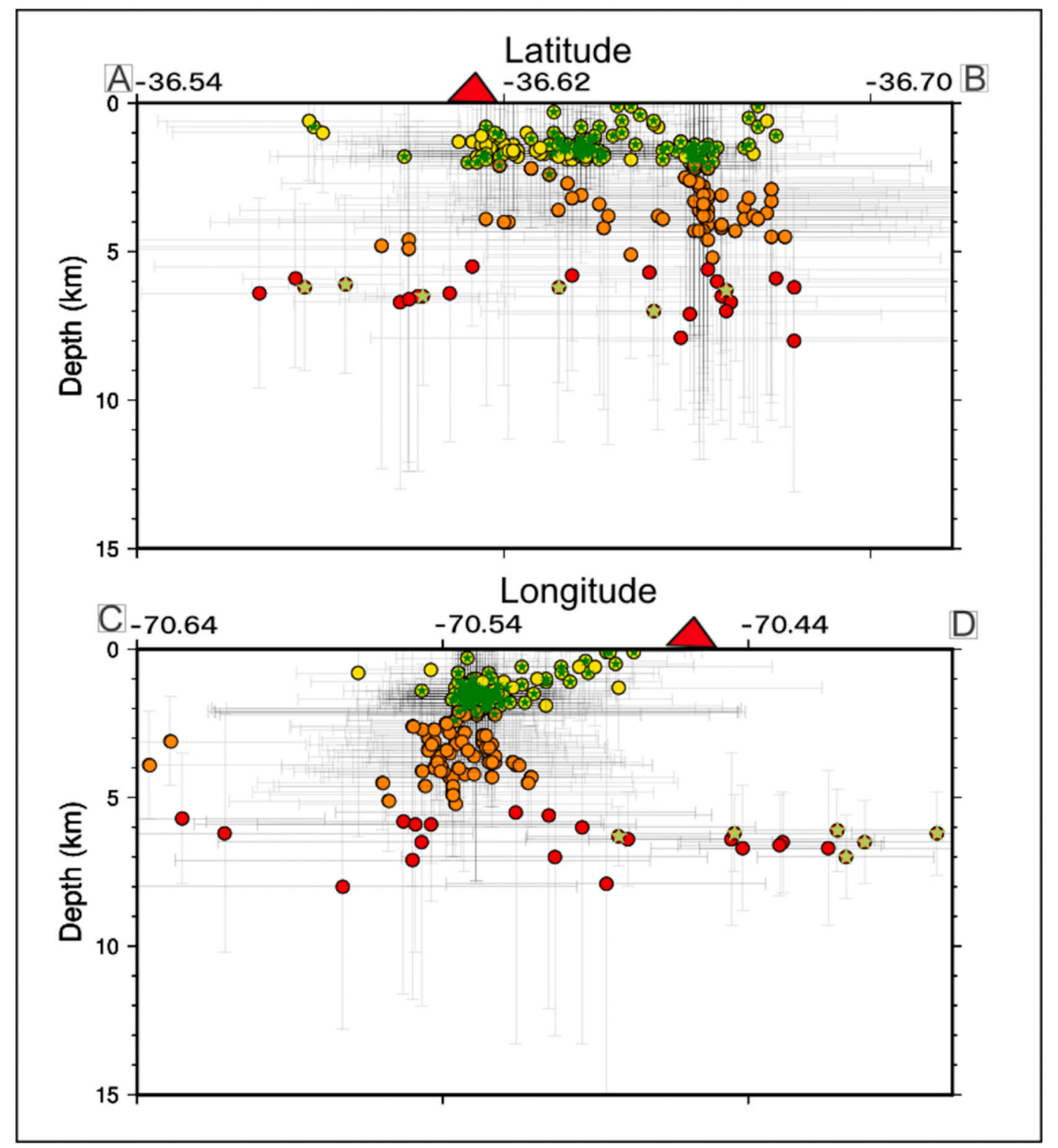

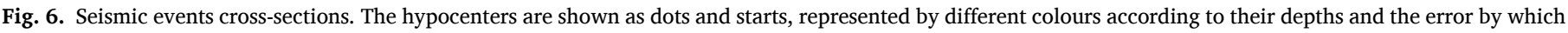

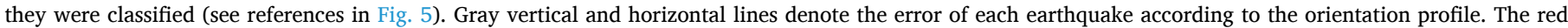

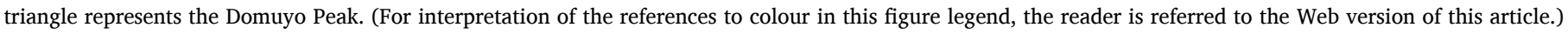

select those events with error in latitude and longitude of less than $5 \mathrm{~km}$ and less that $2 \mathrm{~km}$ in depth error, obtaining a total of $133 \mathrm{VT}$ events. Is important clarify that the hypocentral errors were calculated considering a confidence level of $90 \%$. For these events we found a Gaussian error distribution in their horizontal and vertical errors. In Figs. 5 and 6 we show the two set of events using 2 different depth colours scales. Also, in Table 1 of Appendix, we present the $255 \mathrm{~V}$ T events in which the $113 \mathrm{~V}$ T events are included. The calculated local magnitude of the VT events varies from -1 to 1.5 (Histogram in Fig. 5). The two selections show that all the events are surrounding the Cerro Domuyo, noteworthy the major concentration of VT events is at the geothermal field. These events were located over the Manchana Covunco fault or in the vicinity of that fault. Notably, the shallow events, (depth less than $3 \mathrm{~km}$ ) occurred at the intersection of Manchana Covunco and Humazo faults.

Regarding errors, focal depth is one of the hardest parameters to determine as it is evidenced by the contrast between vertical and horizontal errors. The comparison of the events distribution with a more restrictive criterion, considering the "loose" and the "tight" selection, suggests that these are clustered at two different ranges of depths. A shallow group (78\%) with events located above the $3.5 \mathrm{~km}$ depth and a deep group ( 6 events) with events located between 5 and $8 \mathrm{~km}$ depth (Fig. 6). Considering the "tight" group, events with an error of less than $2 \mathrm{~km}$ in the vertical direction, there is a spatial relation with the El Humazo and La Bramadora geothermal manifestations (red and blue circles in Fig. 2). The seismicity analysis from west to east (cross section C-D in Fig. 6), shows a clear tendency for the shallow seismicity to settle at the geothermal region delimited in Fig. 5 with a red box. Contrary, there is a lack of seismicity of similar focal depths below the Cerro Domuyo peak. This lack of events suggests that the shallow seismicity reflects a local effect mostly related to the widely documented geothermal activity (JICA, 1983, 1984; Mas et al., 2009; Tassi et al., 2016). On the other hand, deeper seismicity (dark green stars in C-D cross section in Fig. 6) located below and to the east of the peak of Cerro Domuyo, is probably a consequence of a greater scale effect recently 


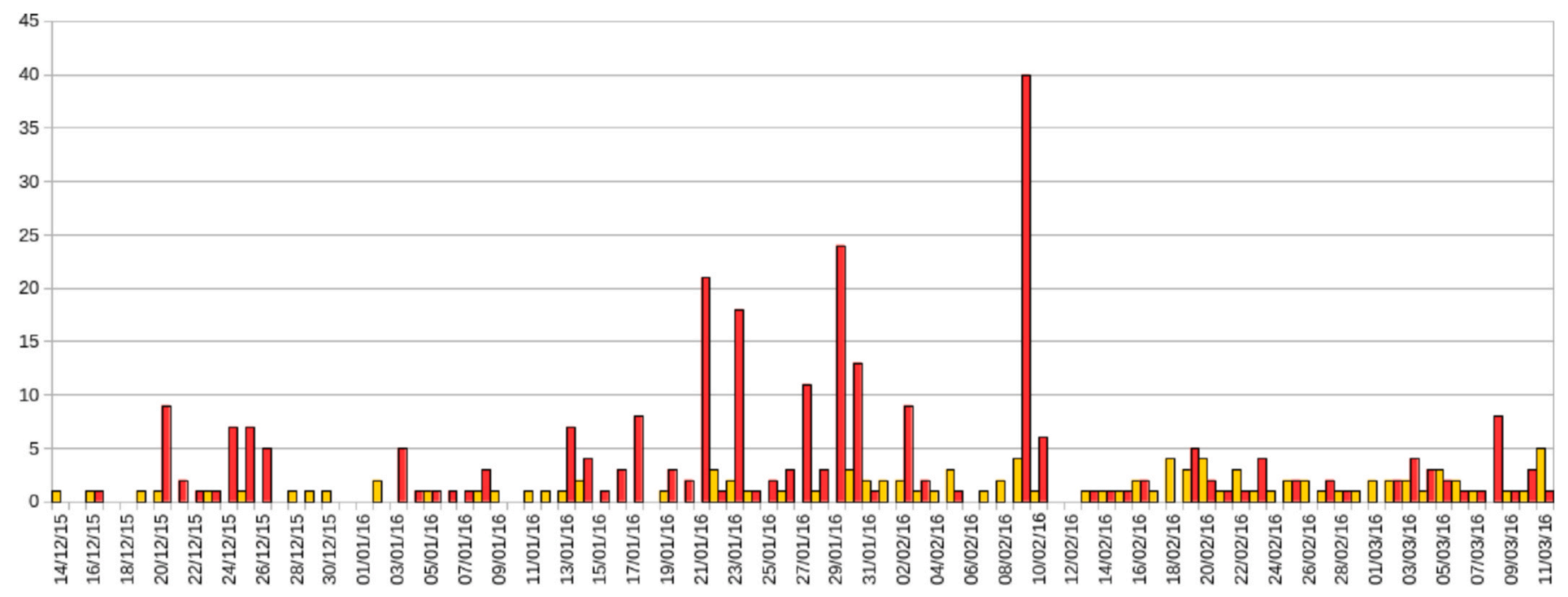

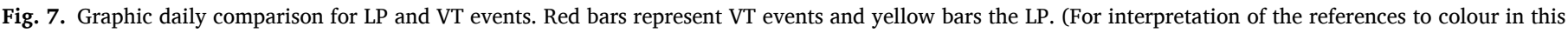
figure legend, the reader is referred to the Web version of this article.)

evidenced (Tassi et al., 2016; Lundgren et al., 2018; Astort et al., 2019).

Volcanic events often occur in swarms, which are groups of many small events with similar magnitudes and locations. The number of VT events per day in the study area were distributed in many swarms with more than 10 events each one. The most prominent group (60 events) was placed near the documented activity associated at El Humazo geothermal explosion in 2003 (Mas et al., 2009). As previously mentioned, LP events were not located but were counted per day and compared with VT events. The daily histogram for the duration of the experiment presented in Fig. 7 suggest no direct association between these events in time, at least for the experiment period.

The reduced-to-the-pole magnetic anomalies and two W-E curie profiles for the Cerro Domuyo and adjacent areas are presented in Fig. 8. Two profiles were located above the Cerro Domuyo ( $\mathrm{AB}$ cross section) and $11 \mathrm{~km}$ to the south (CD cross section). The RTP map shows high magnetic susceptibility zones, probably associated with a paleo-magma chamber. According to the magnetic data, the thinnest magnetic crust (5-6 km) is located at the Cerro Domuyo zone while to the south a magnetic crust of $9 \mathrm{~km}$ or more is expected. This result is consistent with a shallower curie isotherm for the Cerro Domuyo region, which points out a thermal anomaly in this region. In Fig. 9, we plot the "tight" selected events, the locations of the two aquifers (one aquifer at $600 \mathrm{~m}$ and the other at 2000-3000 m) identified by JICA in 1984 and the Curie isotherm obtained in this work. The VT events were grouped at two depths, the great majority between 0.3 and $1.7 \mathrm{~km}$ in the vicinity of the aquifers, and the rest located between $6 \mathrm{~km}$ and $6.9 \mathrm{~km}$ depth.

Tassi et al. (2016) affirm the existence of a hot aquifer near to the surface and consider that the heat comes from a magma source, whose location is unknown but is actively degassed. Recent studies using interferometry techniques demonstrated an inflation of $12 \mathrm{~cm} / \mathrm{yr}$ (Lundgren et al., 2018), covering an area of more than $300 \mathrm{~km}^{2}$ for the Cerro Domuyo region (Astort et al., 2019). These authors proposed a magma body at approximately $6 \mathrm{~km}$ depth to explain their observations. This chamber is consistent and correlates with deeper events located in this work. Probably, this magma body is changing the stress regime of the region activating deep seismicity and increasing significantly the geothermal activity evidenced by high-density shallow seismicity.

Pesce (2013) considers the Cerro Domuyo as an inactive volcano, whose last volcanic manifestation was at 0.11 my. Nevertheless, Tassi et al. (2016) detected magmatic degassing from geochemical analysis (and for a place near la Bramadora, yellow triangle in Fig. 9), where mixing with the meteoric aquifer is not important. This finding seems quite unexpected for an inactive volcano. The high seismicity and thermal anomalies found in this work for the Domuyo region are in correlation with recent studies in the area (Tassi et al., 2016; Lundgren et al., 2018; Astort et al., 2019). These anomalies suggest the emplacement or a possible activation of a magmatic body at a depth of approximately $6 \mathrm{~km}$. In order to understand more deeply these new findings and high-density network is necessary in this emblematic region. Mainly to determine the origin of the deep VT events. In this regard, a broad band seismological network covering not only the geothermal region but also the Domuyo eastern region was deployed in December 2019. Data from this network is expected to be available by December 2020.

\section{Conclusions}

The Cerro Domuyo complex is experiencing considerable seismic activity, mostly on its western side in the geothermal region. The volcano-tectonic events are mainly located at depth of less than $8 \mathrm{~km}$ and local magnitudes vary from -1 to 1.5 . A large number (166) of registered hybrid and long-period events are assumed to be related to fluid motion. The great majority of the VT events are located at the intersection between the Humazo and Manchana Covunco faults close to the location of the 2003 geothermal explosion. A large number of volcano-tectonic events at $<3 \mathrm{~km}$ depth are probably associated with the geothermal activity focused on the Manchana Covunco fault (no more than $2 \mathrm{~km}$ to the east). This fault would be acting as a link between the aquifers and the surface. In addition, we consider that the shallow seismicity was produced mainly by the magma source, which is actively degassing (Tassi et al., 2016).

The Curie isotherm profiles based on the aeromagnetic data suggest a thinner magnetic crust associated with thermal attenuation in the Cerro Domuyo region. The deeper events located between 6 and $7 \mathrm{~km}$ (shown in Figs. 5 and 6 with dark green stars and in Fig. 9 with red circles) are possibly a consequence of the emplacement or a probable activation of a magmatic body (Lundgren et al., 2018; Astort et al., 2019) which is inflating the Domuyo region. These results are expected to be tested with the application of different techniques using data from the new broadband seismological network installed during 2019. 


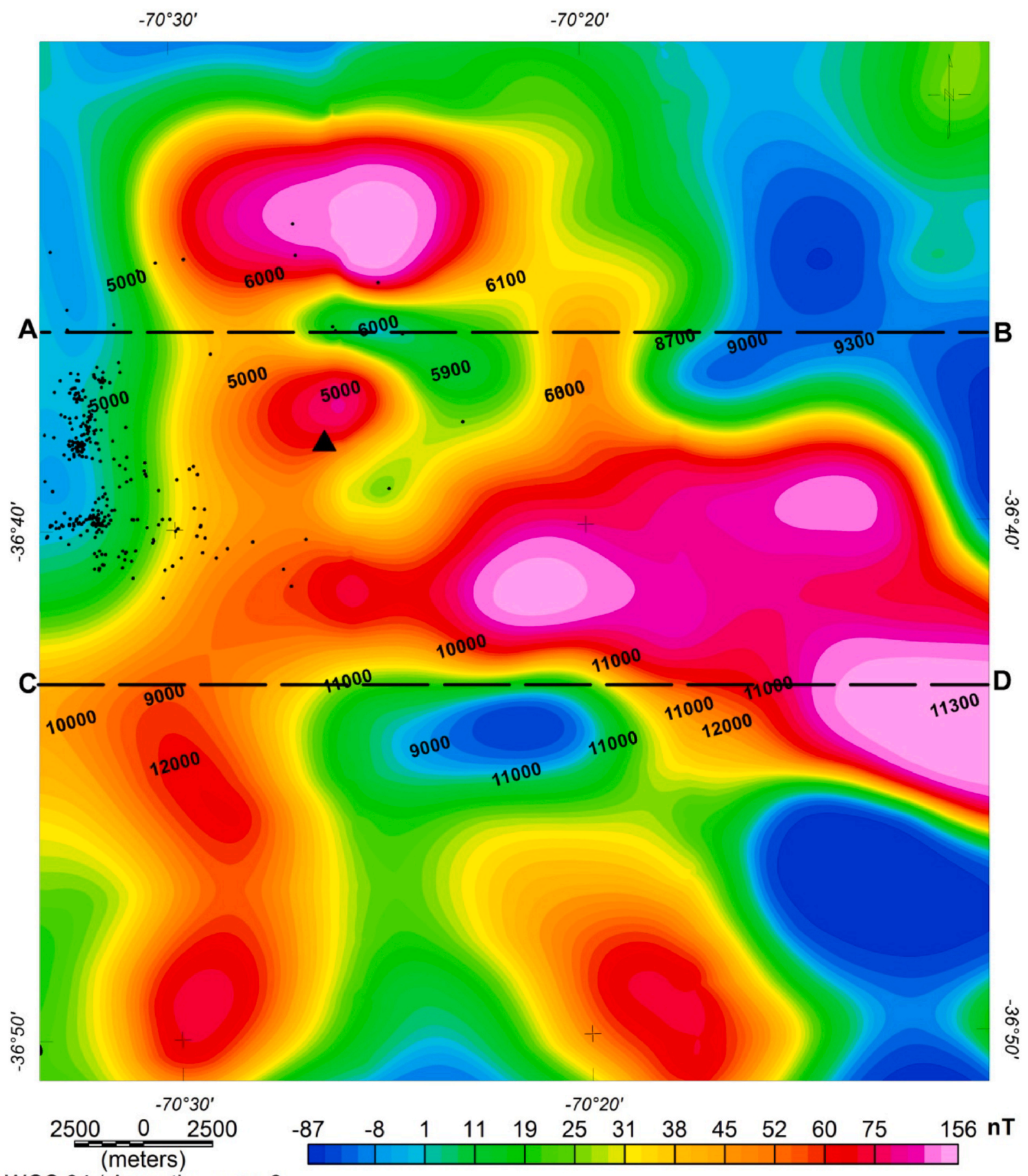

WGS 84 / Argentina zone 2

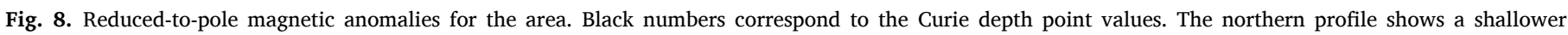
magnetic crust. VT events are shown as black dots. TheDomuyo peak is represented by a black triangle. 


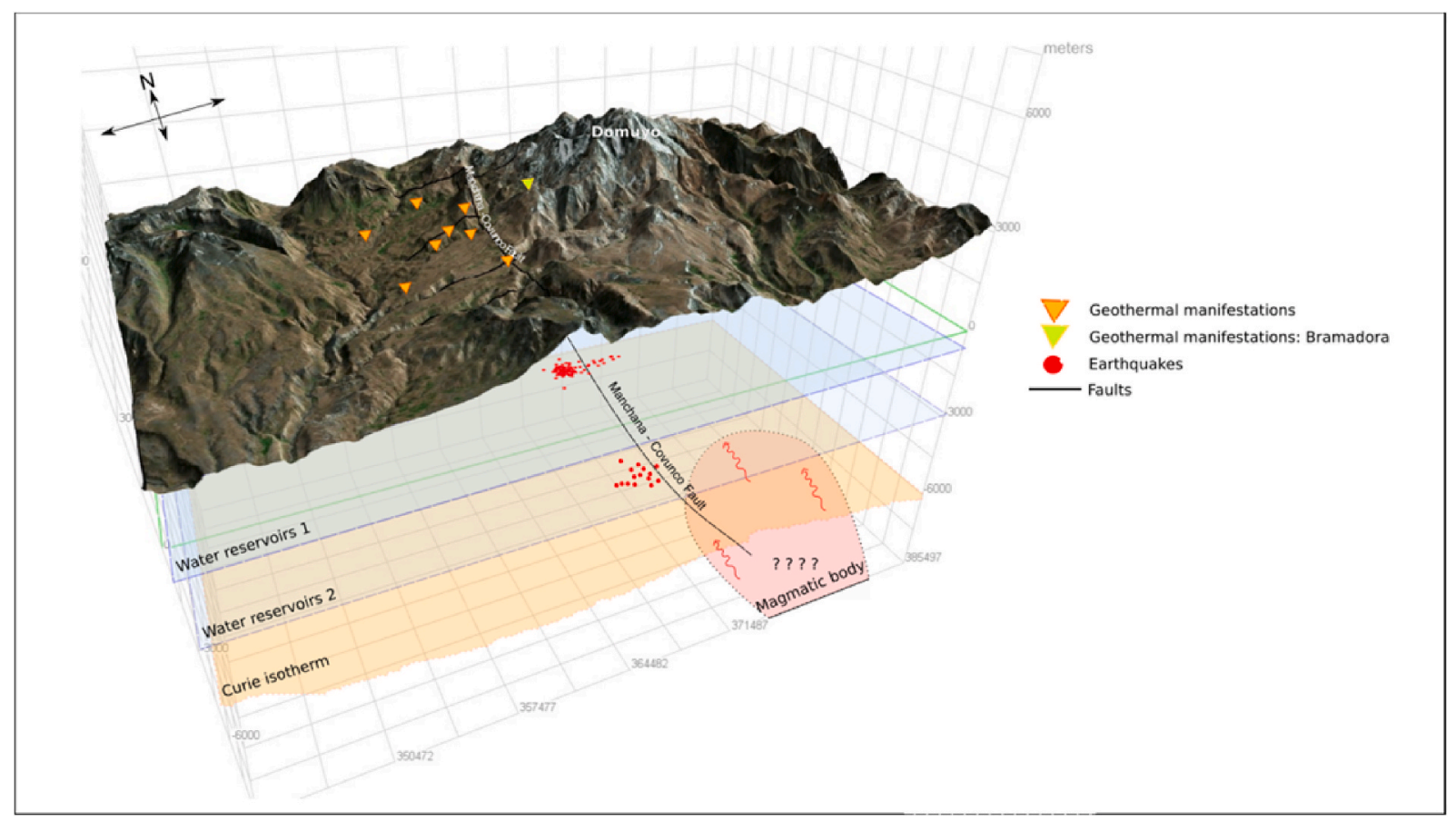

Fig. 9. Model of the Domuyo geothermal system and its connection with the Manchana-Covunco Fault. The location of the water reservoirs and the Curie isotherm (near $6 \mathrm{~km}$ depth) are shown. The hypocenters of the seismic events correspond to VT with errors in the vertical localization of less than $2 \mathrm{~km}$. Events are clustered in two groups according to their depth. The proposed magmatic body is shown in light Pink color. (For interpretation of the references to colour in this figure legend, the reader is referred to the Web version of this article.)

\section{Acknowledgements}

The authors would like to express their deepest gratitude to the anonymous referee for the useful and critical comments of our work. The authors are grateful to FONCYT and CONICET for founding the studies through Projects PICT 2017-1252, PICT 2017-1192, PIP 2015, PIO CONICET-FYPF 13320130100212CO, PIP CONICET Gimenez and PI UNRN 40-A-695. The development of this article was funded by the Doctoral CONICET Fellowship.

\section{Appendix A. Supplementary data}

Supplementary data to this article can be found online at https://doi. org/10.1016/j.jsames.2020.102694.

\section{$\underline{\text { References }}$}

Astort, A., Walter, T.R., Ruiz, F., Sagripanti, L., Nacif, A., Acosta, G., Folguera, A., 2019. Unrest at Domuyo volcano, Argentina, detected by geophysical and geodetic data and morphometric analysis. Rem. Sens. 11 (18), 2175.

Baranov, V., 1957. A new method for interpretation of aeromagnetic maps: pseudogravimetric anomalies. Geophysics 22 (2), 359-382.

Blakely, R.J., 1995. Potential Theory in Gravity \& Magnetic Applications. Cambridge University Press, p. 441.

Bohm, M., Lüth, S., Echtler, H., Asch, G., Bataille, K., Bruhn, C., Rietbrock, A., Wigger, P., 2002. The Southern Andes between $36^{\circ}$ and $40^{\circ}$ S latitude: seismicity and average seismic velocities. Tectonophysics 356, 275-289. https://doi.org/10.1016/S00401951(02)003992.

Briggs, I.C., 1974. Machine contouring using minimum curvature. Geophysics 39 (1), 39-48.

Cardoso, R.R., Hamza, V.M., Alfaro, C., 2010. Geothermal resource base for south America: a continental perspective. In: Proceedings World Geothermal Congress 2010, pp. 25-29. Bali, Indonesia, April 2010.

Chiodini, G., Liccioli, C., Vaselli, O., Calabrese, S., Tassi, F., Caliro, S., Caselli, A., Agusto, M., D'Alessandro, W., 2014. The Domuyo volcanic system: an enormous geothermal resource in Argentine Patagonia. J. Volcanol. Geoth. Res. 274, 71-77.

Chouet, B., 1992. A seismic model for the source of long-period events and harmonic tremor. In: Gasparini, P., Scarpa, R., Aki, K. (Eds.), Volcanic Seismology, vol. 3. IAVCEI Proc. Vol- canal, pp. 133p-156.

Chouet, B., 2003. Volcano seismology. Pure Appl. Geophys. 160 (3-4), 739-788.
Dungan, M.A., Wulff, A., Thompson, R., 2001. Eruptive stratigraphy of the Tatara-San Pedro complex, $36^{\circ} \mathrm{S}$, Southern Volcanic Zone, Chilean Andes: reconstruction method and implications for magma evolution at long-lived arc volcanic centers. J. Petrol. 42 (3), 555-626.

Espinosa-Cardeña, J.M., Campos-Enriquez, J.O., 2008. Curie point depth from spectral analysis of aeromagnetic data from Cerro Prieto geothermal area, Baja California, Mexico. J. Volcanol. Geoth. Res. 176 (4), 601-609.

Galetto, A., García, V., Caselli, A., 2018. Structural controls of the Domuyo geothermal field, southern Andes ( $36^{\circ} 38^{\prime}$ S), Argentina. J. Struct. Geol. 114, 76-94.

Havskov, J., Ottemoller, L., 2001. Seisan: the Earthquake Software.

Hickey-Vargas, R., Gerlach, D., Frey, F., 1984. Geochemical variations in volcanic rocks from central-south Chile $\left(33^{\circ}-42^{\circ} \mathrm{S}\right)$ : implications for their petrogenesis. In: Harmon, R., Barreiro, B. (Eds.), Andean Magmatism: Chemical and Isotopic Constraints. Shiva Publishing Limite, England, pp. 72-95.

Hickey-Vargas, R., Frey, F.A., Gerlach, D.C., López-Escobar, L., 1986. Multiple sources for basaltic arc rocks from the Southern Volcanic Zone of the Andes ( $\left.34^{\circ}-41 S\right)$ : trace element and isotopic evidence for contributions from subducted oceanic crust, mantle and continental crust. J. Geophys. Res. 91, 5963-5983.

Hickey-Vargas, R., Moreno, H., López Escobar, L., Frey, F., 1989. Geochemical variations in Andean basaltic and silicic lavas from the Villarrica-Lanín volcanic chain

(39.5 S): an evaluation ofsource heterogeneity, fractional crystallization and crustal assimilation. Contrib. Mineral. Petrol. 103, 361-386.

Hildreth, W., Moorbath, S., 1988. Crustal contributions to are magmatism in the Andes of central Chile. Contrib. Mineral. Petrol. 98, 455-489.

Hsieh, H.H., Chen, C.H., Lin, P.Y., Yen, H.Y., 2014. Curie point depth from spectral analysis of magnetic data in Taiwan. J. Asian Earth Sci. 90, 26-33.

JICA, 1983. Interim Report on the Northern Neuquén Geothermal Development Project. First-Second Phase Survey. Japan International Cooperation Agency-Ente Provincial de Energía de la Provincia de Neuquén (unpublished), Neuquén, p. 85.

JICA, 1984. Final Report on the Northern Neuquén Geothermal Development Project. Third Phase Survey. Japan International Cooperation Agency-Ente Provincial de Energía de la Provincia de Neuquén (unpublished), Neuquén, p. 105.

Keidel, J., 1925. Sobre el desarrollo paleogeográfico de las grandes unidades geológicas de laArgentina. Sociedad Argentina de Estudios Geográficos GAEA, Anales 4, 251-312 (Buenos Aires).

Lahr, J.C., Chouet, B.A., Stephens, C.D., Power, J.A., Page, R.A., 1994. Earthquake classification, location, and error analysis in a volcanic environment: implications for the magmatic system of the 1989-1990 eruptions of Redoubt Volcano, Alaska. J. Volcanol. Geoth. Res. 62, 137-152.

Lienert, B.R.E., 1994. HYPOCENTER 3.2: A Computer Program for Locating Earthquakes Locally, Regionally and Globally. Technicalreport, HawaiiInstituteofGeophysics\&Planetology.

Lisjak, M., 2007. Geología, estratigrafía y estructura de las nacientes del arroyo ManchanaCovunco. Área del cerro Domuyo. Neuquén. Degreethesis (unpublished) 100. Universityof Buenos Aires. 
Llambías, E.J., Leanza, H.A., Carbone, O., 2007. Evolución tectono-magmática durante el Pérmico al Jurásico Temprano en la cordillera del Viento ( $\left.37^{\circ} 05^{\prime} \mathrm{S}-37^{\circ} 15^{\prime} \mathrm{S}\right)$ : nuevas evidencias geológicas y geoquímicas del inicio de la cuenca Neuquina. Rev. Asoc. Geol. Argent. 62 (2), 217-235.

López-Escobar, L., Kilian, R., Kempton, P.D., Tagiri, M., 1993. Petrography and geochemistry of quaternary rocks from the southern volcanic zone of the Andes between 4130 'and 46 00'S, Chile. Andean Geol. 20 (1), 33-55.

López-Escobar, L., Cembrano, J., Moreno, H., 1995. Geochemistry and tec- tonics of the Chilean Southern Andes basaltic Quaternary volcanism $\left(37^{\circ}-46^{\circ} \mathrm{S}\right)$ RevistaGeológica de Chile 22, 219-234.

Lundgren, P., Girona, T., Samsonov, S., Realmuto, V., y Liang, C., 2018. Under the radar: new activity beneath the - roof of patagonia", Domuyo volcano, argentinaa. In: AGU Fall Meeting 2018. AGU.

Mariot, M., 2008. Geología y estructura del cerro Domuyo, provincia del Neuquén. Degree thesis (unpublished). University of Buenos Aires, p. 154.

Mas, G.R., Bengochea, L., Mas, L.C., Lopez, N., 2009. Hydrothermal Explosion Due to Seal Ef- Fect in El Humazo Geothermal Manifestation, Domuyo Volcano, Neuquén, Argentina. 34th Workshop on Geothermal Reservoir Engineering Stanford University, Stanford, California, p. 5.

Mas, L.C., Mas, G.R., Bengochea, L., 2011. Recursos geotérmicos. In: XVIII Congreso Geológico Argentino, pp. 820-830. Neuquén.

McNutt, S.R., Roman, D.C., 2015. Volcanic seismicity. In: TheEncyclopedia of Volcanoes, pp. 1011-1034 (AcademicPress)

Pesce, A.H., 1987. Evaluación Geotérmica del Área Cerro Domuyo: Síntesis Estratigráfica, Vulcanológica, Estructural y Geoquímica - modelo Geotérmico Preliminar, provincia del Neuquén, República Argentina. In: Proceedings International Meeting on Geothermics and Geothermal Energy, vol. 5. RevistaBrasileira de Geofísica, Sao Paulo, Brazil, pp. 283-299.

Pesce, A.H., 2013. The Domuyo geothermal area, Neuquén, Argentina. Geothermal Resources Council 37, 309-314.

Pesce, A.H., 2015. Argentina country update. In: Proceedings World Geothermal Congress 2015, pp. 19-25. Melbourne, Australia, April 2015P.

Phillips, J., 2007. Geosoft Executables (GX's) Developed by the US Geological Survey, Version 2.0, with Notes on GX Development from Fortran Code. US Geological Survey. https://pubs.usgs.gov/of/2007/1355/.
Pujol, J., 2000. Joint event location—-the JHD technique and applications to data from local seismic networks. In: Advances in Seismic Event Location. Springer, Dordrecht, pp. 163-204.

Soler, S.R., 2015. Métodos Espectrales para la Determinación de la Profundidad del Punto de Curie y el Espesor Elástico de la Corteza Terrestre. Facultad de Ciencias Exactas, Ingeniería y Agrimensura (FCEIA). Universidad Nacional de Rosario (UNR) (Tesis de Grado para Título de Licenciado en Física. Inédito).

Stipanicic, P.N., Rodrigo, F., Baulíes, O., Martínez, C.G., 1968. Las formaciones presenonianas del denominado Macizo Nordpatagónico y regiones adyacentes. Rev. Asoc. Geol. Argent. 27, 67-98.

Tanaka, A., Okubo, Y., Matsubayashi, 0., 1999. Curie point depth based on spectrum analysis of the magnetic anomaly data in East and Southeast Asia. Tectonophysics $306,461-470$.

Tassi, F., Liccioli, C., Agusto, M., Chiodini, G., Vaselli, O., Calabrese, S., Pecoraino, G., Tempesti, L., Caponi, C., Fiebig, J., Caliro, S., Caselli, A., 2016. The hydrothermal system of the Domuyo volcanic complex (Argentina): a conceptual model based on new geochemical and isotopic evidences. J. Volcanol. Geoth. Res. 328, 198-209.

Thorpe, R.S., 1984. The tectonic setting of active Andean volcanism. In: En Harmon, R.S., y Barreiro, B.A. (Eds.), Andean Magmatism. Shiva Publications Limited, Cheshire, pp. 4-8.

Thorpe, R.S., Francis, P.W., 1979. Variations in Andean andesite compositions and their petrogenetic significance. Tectonophysics 57 (1), 53-70.

Tormey, D.R., Hickey-Vargas, R., Frey, F.A., López-Escobar, L., 1991. Recent lavas from the Andean volcanic front ( 33 to $42^{\circ} \mathrm{S}$ ); interpretations of a long-arc compositional features. In: Harmon, R.S., Rapela, C.W. (Eds.), Andean Magmatism and its Tectonic Setting, vol. 265. Geological Society of America, pp. 57-77.

Yrigoyen, M., 1972. Cordillera Principal. Geología Regional Argentina, vol. 1. Academia Nacional de Córdoba, Córdoba, pp. 345-364.

Yrigoyen, M., 1979. Cordillera Principal. $2^{\circ}$ Simposio de Geología Regional Argentina, vol. 1. Academia Nacional de Ciencias de Córdoba, Córdoba, pp. 651-694.

Zanettini, J.C.M., 2001. Hoja Geológica 3772-II, Las Ovejas. Provincia del Neuquén, vol. 263. Instituto de Geología y Recursos Minerales, Servicio Geológico Minero Argentino, Buenos Aires, Boletín, p. 61.

Zappettini, E., Méndez, V., Zanettini, J.C., 1987. Metasedimentitasmesopaleozoicas en el noroeste de la Provincia del Neuquén. Rev. Asoc. Geol. Argent. 42 (1-2), 206-207. 